\title{
The effects of fall fertilization on the growth of Chinese pine and Prince Rupprecht's larch seedlings
}

\author{
Yan $\mathrm{Zhu}^{1,2} \cdot$ Shan $\mathrm{Li}^{3}$ - Caiyun Wang ${ }^{1,2}$.

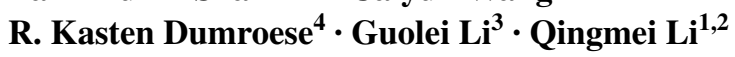

Received: 23 May 2019 / Accepted: 4 August 2019 / Published online: 17 October 2019

(C) The Author(s) 2019

\begin{abstract}
Nutrient loading in the fall is a practical way to improve seedling quality and has been proven to increase nutrient accumulation, translocation and utilization. Few studies have reported on the variation in free amino acids as a result of fall fertilization, especially for different seasonal needle habits (evergreen, deciduous). Therefore, a balanced two-factor factorial design with one fall fertilization treatment (10 mg N/seedling) and Chinese pine (Pinus tabulaeformis Carr.) and Prince Rupprecht's larch (Larix principis-rupprechtii Mayr.) seedlings was used to examine growth response over one nursery season. Associated changes between fall fertilization, $\mathrm{N}$ storage and free amino
\end{abstract}

Project funding: This research was supported by the Chinese Academy of Forestry, Central Public Welfare Research Institutes' Special Funds for Basic Scientific Research (CAFYBB2014QA002).

The online version is available at http://www.springerlink.com.

Corresponding editor: Yanbo Hu.

Yan Zhu

zhuyanzi522@163.com

Qingmei Li

liqm99@163.com

1 Research Institute of Forestry, Chinese Academy of Forestry, Beijing, People's Republic of China

2 Key Laboratory of Tree Breeding and Cultivation of the State Forestry and Grassland Administration, Beijing, People's Republic of China

3 Ministry of Education Key Laboratory of Silviculture and Conservation, Beijing Forestry University, Beijing, People's Republic of China

4 Moscow Forestry Sciences Laboratory, Rocky Mountain Research Station, U.S. Department of Agriculture, Moscow, ID, USA acids were analyzed. Results showed that: (1) stem height, diameter and biomass for both species were similar between controls and fall fertilization treatments; (2) compared to controls, fall fertilization increased Chinese pine needle and root $\mathrm{N}$ by $17.7 \%$ and $36.9 \%$, respectively. For Prince Rupprecht's larch, fall fertilization resulted in $26.3 \%$ and $34.54 \%$ more $\mathrm{N}$ in stem and roots, respectively, than controls; (3) the three main amino acids in control and fertilization treatments in Prince Rupprecht's larch seedlings were glutamine, arginine and proline, and in Chinese pine seedlings were glutamine, arginine and $\gamma$-amino butyric acid; (4) total amino acid contents were not significantly increased by fall fertilization, but glutamine in Chinese pine and Prince Rupprecht's larch increased by $64.2 \%$ and $35.2 \%$, respectively. Aboveground biomass of Prince Rupprecht's larch had higher proline contents than Chinese pine, which suggests that the stress resistance of the aboveground tissue may be higher for Prince Rupprecht's larch. The results indicate that different plant organs with various response are well adapted to nitrogen loading for nutrient storage in evergreen and deciduous conifer seedlings.

Keywords Amino acids $\cdot$ Fall fertilization $\cdot$ Larix principis-rupprechtii $\cdot$ Seedling quality $\cdot$ Pinus tabulaeformis

\section{Introduction}

When seedlings are transplanted from the nursery to the planting site, their physiological activities have not fully recovered from the move. The ability of roots to obtain soil nutrients is initially low and growth depends on stored nutrients that are transferred to new buds, leaves, roots and reproductive organs (Grossnickle 2005). During nursery 
production, fall fertilization is a practical technique to supply nutrients during the hardening-off stage that occurs at the end of the growing season. These nutrients are "loaded" to promote post-planting retranslocation and frost resistance (Oliet et al. 2013). Therefore, the objective of fall fertilization is to increase nutrient reserves that foster additional growth in the following spring (Villar-Salvador et al. 2015). This procedure has been used to combat nutrient deficiencies in seedlings of Douglas-(Mirb.) Franco (Birchler et al. 2001), red pine (Pinus resinosa Ait.) (Islam et al. 2009) and Chinese cork oak (Quercus variabilis Blume) (Wang et al. 2016).

Nitrogen $(\mathrm{N})$ is a chemical element that limits seedling growth in northern coniferous forests (Rennenberg et al. 2009). Seedling growth may be stimulated with the addition of a nitrogen substrate. Nitrogen reserves are often diluted during the fall when biomass accumulation in juvenile trees continues in the absence of regular fertilization, thus generating the necessity for fall $\mathrm{N}$ fertilization (Oliet et al. 2011; Wei et al. 2014). Several studies have shown that foliage is the major $\mathrm{N}$ sink in evergreen seedlings at the end of growing season (Van den Driessche 1985; Millard and Grelet 2010), while for deciduous conifer seedlings, stems and roots are the main nutrient storage organs. Although nutrient translocation from old leaves may occur, fall fertilization is still an effective way to improve $\mathrm{N}$ levels of stems and roots (Zhu et al. 2013).

In the process of leaf aging during autumn, functional proteins in senescing leaves are broken down into small molecules of amino acids which further form amino acid compounds that are transported to the xylem of roots and stems where vegetative storage proteins (Stepien et al. 1994) are synthesized. There are no seasonal concentrations in deciduous leaves of evergreen species, and leaves often become organs for storing N (Millard and Proe 1992). Leaves of evergreen species in the spring are "sources" of stored N to new tissues. Thus, unlike deciduous tree species, leaves of evergreen species make an important impact in the circulation of $\mathrm{N}$ within the plant. Therefore, as $\mathrm{N}$ carrier substances, amino acids may be different between evergreen and deciduous species at the end of the growing season.

Research into $\mathrm{N}$ metabolism is a unique way to explain the physiological status of seedlings. Some researchers have found that during the hardening-off phase, $\mathrm{N}$ was mainly stored as protein, amino acid, ammonium $\mathrm{N}$, nitrate $\mathrm{N}$ and other metabolites in seedlings. Among the amino acids, arginine was found to be the main form of stored $\mathrm{N}$ during dormancy in poplar (Rennenberg et al. 2010). In the next spring, some proteins broke down into glutamic acid, aspartic acid and other amino acids and were transported to new buds, leaves, and roots and used to synthesize endogenous proteins for tissue growth (Wildhagen et al. 2010; Lee et al. 2014). While research on amino acid composition in seedlings has received attention, it is unclear how fall fertilization with $\mathrm{N}$ affects seedling quality and if these $\mathrm{N}$ additions have an effect on storage proteins. From the response of various amino acids in seedlings to $\mathrm{N}$ fluctuation, it is helpful to understand the process of $\mathrm{N}$ storage and utilization to reveal the physiological basis of fall fertilization.

Prince Rupprecht's larch (Larix principis-rupprechtii Mayr.) and Chinese pine (Pinus tabulaeformis Carr.) are representative deciduous and evergreen species in northern China and widely used for afforestation because of their rapid growth rates and high-quality timber ( $\mathrm{Wu}$ and $\mathrm{Nioh}$ 1997). However, their planting regions are often exposed to environmental stresses (Wu and Feng 1994). Nutrient loading has been shown to promote nutrient reserves (Wang et al. 2015), increase stress resistance and improve out-planting performance (Oliet et al. 2013). Moreover, deciduous conifer and evergreen seedlings have different nutrient storage strategies (Zhu et al. 2013; Villar-Salvador et al. 2015). Therefore, to determine which amino acids are involved in $\mathrm{N}$ recycling and storage will help improve understanding of the benefits of nutrient loading for afforestation. The objectives of this study were to: (1) examine $\mathrm{N}$ uptake characteristics of coniferous seedlings with different seasonal needle habits (evergreen, deciduous) after fall fertilization; and, (2) investigate the effects of fall fertilization on amino acid levels in different organs of coniferous seedlings. To achieve these objectives, a ${ }^{15} \mathrm{~N}$-labeling experiment was carried out using deciduous and evergreen coniferous species to trace the quantity of applied nitrogen for reserves and the types of amino acid presents.

\section{Materials and methods}

\section{Plant material and cultural conditions}

Chinese pine and Prince Rupprecht's larch seeds were obtained from Qigou Forest Farm seed orchards and Mulan Weichang, respectively. The seeds were soaked for $24 \mathrm{~h}$ in running water at room temperature. For each species, 784 seeds (16 trays $\times 49$ containers) were sown and raised in a greenhouse at the Chinese Academy of Forestry in Beijing under natural light and day: night temperatures of $26^{\circ} \mathrm{C}$ and $14{ }^{\circ} \mathrm{C}$. The containers were filled with a $3: 1$ (v:v) peat: perlite mixture and watered twice a week. Three weeks after sowing, the seedlings were thinned to one per container.

Pre-hardening nitrogen fertilization continued for 16 weeks using irrigation water with soluble fertilizer: $20 \mathrm{~N}\left(3.2 \mathrm{NH}_{4}^{+}\right.$; $5.3 \mathrm{NO}_{3}^{-} ; 11.5$ urea): $20 \mathrm{P}\left(\mathrm{P}_{2} \mathrm{O}_{5}\right): 20 \mathrm{~K}\left(\mathrm{~K}_{2} \mathrm{O}\right): 0.05 \mathrm{Mg}$, $0.0125 \mathrm{~B}, 0.0125 \mathrm{Cu}, 0.05 \mathrm{Fe}, 0.025 \mathrm{Mn}, 0.005 \mathrm{Mo}, 0.025 \mathrm{Zn}$ (Everris NA Inc, Dublin, OH, USA). The supply rates were applied following the exponential function weekly (Wang et al. 2015) with a total of $25 \mathrm{mg} \mathrm{N}$ seedling ${ }^{-1}$ (Zhu et al. 2013). To 
minimize edge effects, the containers were rotated biweekly within trays.

Two weeks after the pre-hardening fertilization ended, fall fertilization started when most seedlings had formed terminal buds. For each species, $10 \mathrm{mg} \mathrm{N}$ seedling $^{-1}$ were applied in four replications, with $\mathrm{N}$ as ${ }^{15} \mathrm{NH}_{4}^{15} \mathrm{NO}_{3}$ and enriched to 10.2 atom\% (Shanghai, China). Applications were evenly split and applied for 4 weeks. To minimize the amount of leaching, seedlings were irrigated less than the container capacity.

\section{Plant sampling and analysis}

Ten seedlings were randomly sampled from each replication (40 per treatment) for both species to evaluate growth, nutrient storage, and amino acid levels. Seedlings were rinsed in deionized water and root collar diameter (RCD) and height measured, and partitioned into needles, stems and roots. Half of the seedlings (five per replication per species) were oven-dried at $65{ }^{\circ} \mathrm{C}$ to constant mass (approximately $72 \mathrm{~h}$ ) and weighed. The five seedlings within each fertilized-replication combination were then bulked and ground for each organ (root, stem, needles). The ${ }^{15} \mathrm{~N}$ analysis and total $\mathrm{N}$ determination in each sample were conducted at the China Agricultural University, Beijing.

Another five seedlings were separated into needles, stems, and roots, and immediately frozen in liquid $\mathrm{N}_{2}$ and stored at $-80{ }^{\circ} \mathrm{C}$ for analyses. Each tissue sample was ground in liquid $\mathrm{N}_{2}$ and free amino acids were extracted with $300 \mu \mathrm{l}$ of acetonitrile and $300 \mu \mathrm{l}$ of deionized water from $150 \mathrm{mg}$ of homogenized frozen tissue powder. For this process, the mixture underwent ultrasonic extraction for $1 \mathrm{~h}$; the extract was centrifuged at $13,200 \mathrm{r} / \mathrm{min}$ for $10 \mathrm{~min}$ at $4{ }^{\circ} \mathrm{C}$. The supernatant was measured by the HPLC-MS method (Hu et al. 2013). Amino acid content was determined by BEH Amide, $1.7 \mathrm{mu}$ M, $100 \times 2.1 \mathrm{~mm}$ column (liquid phase model UltiMate 3000, Thermo Scientific ${ }^{\mathrm{TM}}$ production; mass spectrometry model is Q Exactive ${ }^{\mathrm{TM}}$ production).

\section{Statistical analysis}

Data were analyzed using SPSS 18.0 software (SPSS ${ }^{\circledR}$, Chicago, IL, USA). Two-factor analysis of variance (ANOVA) was used to analyze the effects of species (deciduous larch or evergreen pine) and fall fertilization (10 $\mathrm{mg} \mathrm{N}$ ) and their interactions. For each analysis, the means among species/treatment were compared by the method of Duncan multiple range test at the 0.05 level.

\section{Results}

\section{Seedling growth}

Fall fertilization did not significantly affect stem height, RCD (root collar diameter) or organ biomass of either species while the growth between species was significantly different. Larch seedlings were significantly taller than the pines $(11.0 \pm 0.4 \mathrm{~cm}$ vs. $5.6 \pm 0.1 \mathrm{~cm})(p<0.05)$. Under the same cultivation conditions, pine biomass was three times that of larch. Biomass allocation also differed markedly, with larch biomass concentrated in stems and roots pine biomass primarily in needles and roots (Fig. 1).

\section{Proportion of $\mathrm{N}$ in organs}

With the exception of pine stems, $\mathrm{N}$ concentration, $\mathrm{N}$ content and ${ }^{15} \mathrm{~N}$ contents of all organs in fertilized seedlings of both species were significantly higher than those of the controls (Fig. 2A-C). Fall fertilization increased the $\mathrm{N}$ concentration in pine needles and roots by $17.7 \%$ and $36.9 \%$, respectively. Nitrogen concentrations were highest in needles, followed by roots and stems. However, $\mathrm{N}$ contents of needles and roots were not significantly different, whether in controls or in $10 \mathrm{mg} \mathrm{N}$ treated seedlings, but accounted for $85 \%$ of the total $\mathrm{N}$ content, significantly higher than that of stems. Pine seedlings allocated most of the assimilated ${ }^{15} \mathrm{~N}$ to needles and roots.

For larch, fall fertilization increased $\mathrm{N}$ levels in stems and roots by $26.3 \%$ and $34.54 \%$, respectively, compared to the controls (Fig. 2). The ${ }^{15} \mathrm{~N}$ contents of the stems and roots in fertilized seedlings were highly enriched: 10.8 and 12.3 times greater, respectively.

Significant species $\times$ seedling organ interactions were observed for $\mathrm{N}$ contents and ${ }^{15} \mathrm{~N}$ contents $(p<0.001$, data

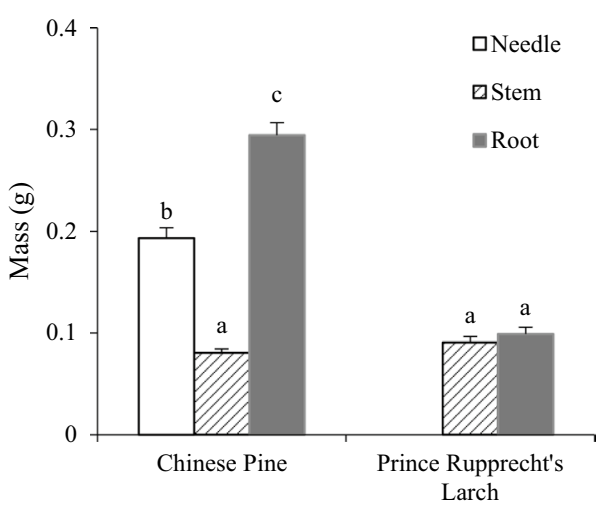

Fig. 1 Seedling biomass allocation for organs of Chinese pine and Prince Rupprecht's larch seedlings at the end of the growing season. Columns with the same letter do not differ significantly at the 0.05 level 

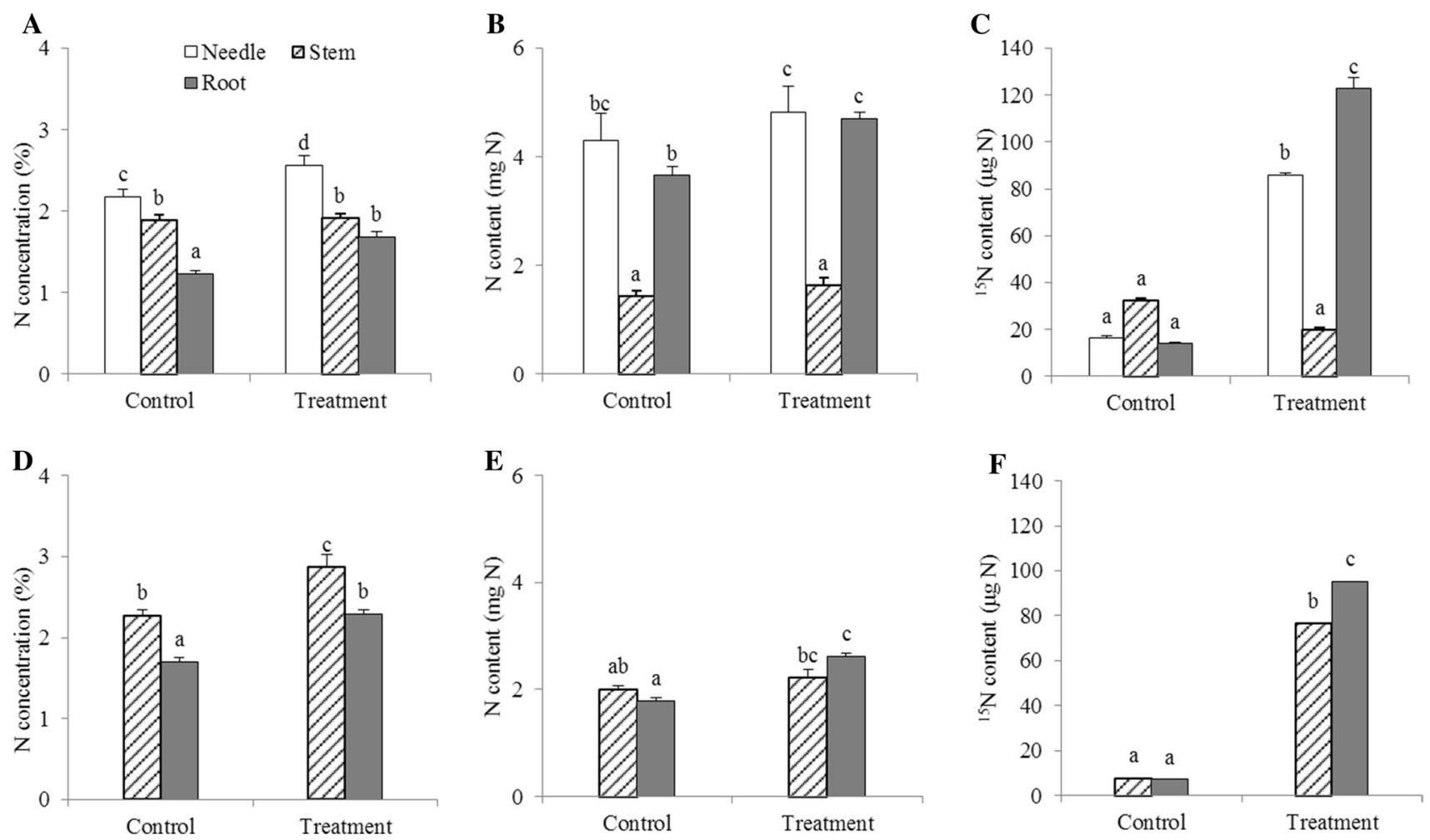

Fig. $2 \mathrm{~N}$ concentration, content, and ${ }^{15} \mathrm{~N}$ content of needles, stems and roots of controls and fall fertilization of Chinese pine and Prince Rupprecht's larch seedlings. Values are mean $\pm \mathrm{SE}$ and columns with same letter do not differ significantly at 0.05 level

not shown). Nitrogen concentration in stems and roots of larch exceeded those of the corresponding organs in pine. However, pine needles and roots exhibited greater $\mathrm{N}$ and ${ }^{15} \mathrm{~N}$ contents than larch. Both species allocated higher amounts of assimilated ${ }^{15} \mathrm{~N}$ to roots, with lower amounts allocated to pine needles and larch stems.

\section{Storage of amino acids}

The majority of amino acids in Chinese pine were translocated as glutamine (Gln), arginine (Arg) and $\gamma$-amino butyric acid (GABA), accounting for $61.3 \%$ and $70.5 \%$ of free amino acids, respectively, in the controls and fertilized seedlings. The main free amino acids stored in larch seedlings were Gln, Arg and proline (Pro), accounting for 59.9\% of amino acids in the controls and $60.8 \%$ of those in the fertilized seedlings (Table 1). The total amino acid content in both fertilized species was slightly higher compared with the controls, but there were no significant differences.

The contents of the four amino acids (Arg, GABA, Gln and Pro) were significantly influenced by species, organ and species $\times$ fertilization interaction. Only glutamine levels were affected by fall fertilization. GABA, by contrast, was significantly different in species and organs except for fertilized species. Compared with the control seedlings, fall fertilization increased the Gln content in pine and larch by $35.2 \%$ and $64.2 \%$, respectively. The tissue Gln levels in both species were similar to the patterns of their $\mathrm{N}$ contents (data not shown), but the average value of Gln in Chinese pine was three times greater than in the larch seedlings (Table 2).

For larch seedlings, Gln levels in the stems were significantly higher than in the roots, but the total ${ }^{15} \mathrm{~N}$ enrichment of Arg in the stems and roots exceeded those of Gln (Table 3). For pine seedlings, the ${ }^{15} \mathrm{~N}$ enrichment of the main amino acids were found in the order roots $>$ needles $>$ stems. Roots were significantly enriched with ${ }^{15} \mathrm{~N}$ in Arg, accounting for 55.3\% of the total Arg enrichment in the seedlings. Except for Pro, Chinese pine seedlings allocated more ${ }^{15} \mathrm{~N}$-labeled Arg, GABA and Gln than larch.

\section{Discussion}

\section{Effects of fall fertilization on growth}

Fall fertilization did not affect the morphology and biomass of pine and larch seedlings. Boivin et al. (2002) reported that fertilization in the autumn was beneficial for biomass accumulation during the hardening-off period. However, other studies have indicated that autumn fertilization had 
Table 1 Fall fertilization effect on storage of nitrogen in amino acid $\left(\mu \mathrm{g} \mathrm{seedling}^{-1}\right)$ in seedlings of Chinese pine and Prince Rupprecht's larch

\begin{tabular}{|c|c|c|c|c|}
\hline \multirow[t]{2}{*}{ Amino acid } & \multirow{2}{*}{$\begin{array}{l}\text { Chinese pine } \\
\text { Control }\end{array}$} & \multicolumn{3}{|c|}{ Prince Rupprecht's larch } \\
\hline & & Treatment & Control & Treatment \\
\hline Alanine & $12.1 \pm 1.2$ & $10.4 \pm 0.1$ & $3.3 \pm 0.6$ & $4.4 \pm 1.2$ \\
\hline Arginine & $50.7 \pm 4.6$ & $57.7 \pm 3.8$ & $22.8 \pm 1.3$ & $20.3 \pm 1.3$ \\
\hline Asparagine & $2.1 \pm 0.5$ & $3.1 \pm 3.8$ & $0.6 \pm 0.1$ & $0.7 \pm 0.3$ \\
\hline Aspartate & $21 \pm 3.0$ & $22.6 \pm 2.1$ & $6.9 \pm 0.6$ & $7.6 \pm 1.2$ \\
\hline Citrulline & $0.9 \pm 0.1$ & $0.9 \pm 0.1$ & $2.0 \pm 0.3$ & $1.1 \pm 0.3$ \\
\hline GABA & $32.7 \pm 1.3$ & $28.4 \pm 1.0$ & $6.4 \pm 0.4$ & $7.9 \pm 0.7$ \\
\hline Glutamate & $17.2 \pm 3.6$ & $3.7 \pm 0.7$ & $5.7 \pm 0.6$ & $6.9 \pm 1.4$ \\
\hline Glutamine & $89.2 \pm 6.3$ & $146.5 \pm 14.6$ & $24.6 \pm 3.9$ & $33.2 \pm 9.0$ \\
\hline Glycine & $1.5 \pm 0.0$ & $1.3 \pm 0.1$ & $0.4 \pm 0.0$ & $0.5 \pm 0.1$ \\
\hline Histidine & $1.9 \pm 0.1$ & $1.8 \pm 0.1$ & $1.8 \pm 0.1$ & $1.3 \pm 0.2$ \\
\hline Isoleucine & $1.7 \pm 0.3$ & $2.2 \pm 0.1$ & $0.9 \pm 0.1$ & $1.1 \pm 0.2$ \\
\hline Leucine & $4.5 \pm 0.6$ & $4.8 \pm 0.3$ & $1.6 \pm 0.1$ & $1.9 \pm 0.4$ \\
\hline $\begin{array}{l}\text { L-Methio- } \\
\text { nine }\end{array}$ & $0.3 \pm 0.0$ & $0.3 \pm 0.0$ & $0.1 \pm 0.0$ & $0.1 \pm 0.0$ \\
\hline Lysine & $1.7 \pm 0.1$ & $1.4 \pm 0.1$ & $0.5 \pm 0.0$ & $0.3 \pm 0.0$ \\
\hline Ornithine & $0.8 \pm 0.0$ & $0.7 \pm 0.0$ & $0.4 \pm 0.0$ & $0.2 \pm 0.0$ \\
\hline $\begin{array}{l}\text { Phenylala- } \\
\text { nine }\end{array}$ & $1.8 \pm 0.3$ & $1.8 \pm 0.2$ & $0.5 \pm 0.0$ & $0.5 \pm 0.1$ \\
\hline Proline & $17.7 \pm 2.2$ & $20.1 \pm 2.0$ & $16.3 \pm 0.9$ & $13.7 \pm 1.7$ \\
\hline Serine & $13.5 \pm 0.4$ & $11.6 \pm 0.8$ & $2.0 \pm 0.2$ & $1.9 \pm 0.2$ \\
\hline Threonine & $4.2 \pm 0.3$ & $4.0 \pm 0.2$ & $1.0 \pm 0.1$ & $1.2 \pm 0.2$ \\
\hline Tryptophan & $3.2 \pm 0.2$ & $3.6 \pm 0.4$ & $7.0 \pm 0.2$ & $4.4 \pm 0.5$ \\
\hline Tyrosine & $2.8 \pm 0.3$ & $2.8 \pm 0.3$ & $1.5 \pm 0.1$ & $1.3 \pm 0.2$ \\
\hline Total & $281.7 \pm 8.3$ & $329.7 \pm 22.0$ & $106.1 \pm 9.0$ & $110.5 \pm 15.9$ \\
\hline
\end{tabular}

Data are mean \pm SE of four replicates

no significant effects on biomass (van den Driessche 1985; Boivin et al. 2004; Islam et al. 2009). Pine seedling mass was mainly comprised of needles and roots, with less biomass allocated to stems which is similar to the stem or root biomass of larch (Fig. 1). Although larch seedlings lost some needle biomass when sampled, the ratio of aboveground biomass to underground biomass was close to 1 . For evergreen Chinese pine, this ratio was also nearly 1 . Therefore, regardless of fall fertilization, aboveground and underground biomass distribution of the two species is equal. Unlike these coniferous species, most of the biomass of Chinese cork oak (Quercus variabilis Blume) seedlings fertilized in the autumn was concentrated in the roots at the end of the growing season (Wang et al. 2016), while most poplar biomass was concentrated in stems (Zhao et al. 2017). Both leaf habits and seedling root characteristics are key factors in biomass distribution.

\section{Effects of fall fertilization on $\mathrm{N}$ distribution}

Different patterns of biomass allocation were reflected in the species-specific pattern of $\mathrm{N}$ content (Fig. 2B and E). Nitrogen fertilization in the autumn increased $\mathrm{N}$ contents significantly in both species, but in pine seedlings total $\mathrm{N}$ was $64.9 \%$ greater than that of larch. This difference can be attributed to needle seasonality and ecology of the species.

Additionally, ${ }^{15} \mathrm{~N}$ allocation to Chinese pine roots was significantly higher than to other organs. Likewise, larch seedlings allocated newly acquired ${ }^{15} \mathrm{~N}$ more to roots (Fig. 2C and F). Needles, especially juvenile needles, are the main $\mathrm{N}$ storage sites for evergreen species (Nambiar and Fife 1991; Villar-Salvador et al. 2015). This study has shown that both the roots and needles are important organs of Chinese pine seedlings for nitrogen reserves at the end of the growing season.

\section{Effects of fall fertilization on amino acid levels}

Although several studies have reported on the nutrient effects of fall fertilization, this study reports, for the first time, the responses of amino acids concurrently in deciduous and evergreen coniferous seedlings. The results indicate that fall-applied $10 \mathrm{mg} \mathrm{N}$ per seedling had no effect on the total contents of amino acids and amides, while glutamine was significantly increased in pine and larch seedlings (Table 2). In the present study, the three main amino acids in larch were glutamine, arginine and proline, and in Chinese pine seedlings, glutamine, arginine and $\gamma$-amino butyric acid. In addition, for each species fertilized, the contents of the three main amino acids accounted for more than $60 \%$ of their total amino acid content.

Arginine was the predominant component of storage proteins in Acer pseudoplatanus L. (Millard and Proe 1991), Populus x canescens (Aiton) Sm. (Rennenberg et al. 2010),

Table 2 ANOVA results for arginine, $\gamma$-amino butyric acid, glutamine, and proline contents

\begin{tabular}{lrllllll}
\hline Dependent variable & Species & Fert & Organ & Species $\times$ fert $\times$ organ & Species $\times$ fert & Species $\times$ organ & Fert $\times$ organ \\
\hline Arginine & $<\mathbf{0 . 0 0 1}$ & 0.659 & $<\mathbf{0 . 0 0 1}$ & 0.748 & 0.056 & 0.110 & $<\mathbf{0 . 0 0 1}$ \\
GABA & $<\mathbf{0 . 0 0 1}$ & 0.707 & $<\mathbf{0 . 0 0 1}$ & $\mathbf{0 . 0 0 8}$ & $\mathbf{0 . 0 1 1}$ & $<\mathbf{0 . 0 0 1}$ & $\mathbf{0 . 0 0 5}$ \\
Glutamine & $\mathbf{0 . 0 0 5}$ & $\mathbf{0 . 0 2 1}$ & $\mathbf{0 . 0 0 3}$ & 0.239 & 0.161 & $<\mathbf{0 . 0 0 1}$ & 0.982 \\
Proline & $<\mathbf{0 . 0 0 1}$ & 0.854 & $<\mathbf{0 . 0 0 1}$ & 0.313 & 0.582 & $<\mathbf{0 . 0 0 1}$ & 0.124 \\
\hline
\end{tabular}

$p$ values are shown for the overall model, main effects, and all interactions. Values in bold are significant at $p<0.05$ 
Table 3 Contents of labeled ${ }^{15} \mathrm{~N}$ in arginine, GABA, glutamine and proline $\left(\mu \mathrm{g} \mathrm{seedling}^{-1}\right)$ in fertilized Chinese pine and Prince Rupprecht's larch seedlings

\begin{tabular}{cccll}
\hline \multicolumn{2}{c}{ Arginine } & GABA & Glutamine & Proline \\
\hline \multicolumn{2}{c}{ Chinese pine } \\
Needle & $1.10 \pm 0.22^{\mathrm{a}}$ & $0.31 \pm 0.06^{\mathrm{a}}$ & $3.52 \pm 1.02^{\mathrm{b}}$ & $0.24 \pm 0.07^{\mathrm{a}}$ \\
Stem & $0.84 \pm 0.15^{\mathrm{a}}$ & $0.17 \pm 0.03^{\mathrm{a}}$ & $1.90 \pm 1.11^{\mathrm{ab}}$ & $0.08 \pm 0.07^{\mathrm{a}}$ \\
Root & $2.40 \pm 1.33^{\mathrm{b}}$ & $0.35 \pm 0.23^{\mathrm{a}}$ & $4.04 \pm 2.84^{\mathrm{b}}$ & $0.15 \pm 0.11^{\mathrm{a}}$ \\
Prince Rupprecht's larch & & & \\
Stem & $1.50 \pm 0.07^{\mathrm{ab}}$ & $0.19 \pm 0.04^{\mathrm{a}}$ & $2.62 \pm 1.43^{\mathrm{b}}$ & $0.40 \pm 0.14^{\mathrm{b}}$ \\
Root & $1.85 \pm 0.36^{\mathrm{ab}}$ & $0.17 \pm 0.05^{\mathrm{a}}$ & $0.08 \pm 0.13^{\mathrm{a}}$ & $0.11 \pm 0.05^{\mathrm{a}}$ \\
\hline
\end{tabular}

Column mean \pm SE followed by different letters within a given treatment differ significantly according to Duncan's multiple range test at the 0.05 level

and Amygdalus spp. (Munoz et al. 1993), but glutamine was the predominant $\mathrm{N}$ form on the Prunus avium L. (Grassi et al. 2002), Picea abies (L.) Karst. (Weber et al. 1998), and Vitis vinifera L. (Peuke 2000) sap during remobilization. In this study, both glutamine and arginine were the predominant forms of amino $\mathrm{N}$ compounds in the two species.

Glutamic acid can be directly transformed into a-ketoglutarate and oxaloacetic acid, intermediate products of the plant tricarboxylic acid cycle (Hu and Sun 2010), so as to provide sufficient adenosine triphosphate quickly when plants need energy. The occurrence of abundant glutamine at the end of the growing season, a common amino acid during $\mathrm{N}$ retranslocation, indicates that fall fertilization allows seedling root systems to still have very active nutrient transfer.

Proline is considered to be a cryoprotectant, preventing the freezing of tissues in many plant species (Krasensky and Jonak 2012). In larch, the content of proline was slightly lower than glutamine and arginine, and higher in stems than in roots. Further, the aboveground biomass of Prince Rupprecht's larch had higher proline levels than Chinese pine. This suggests that the resistance of aboveground biomass to freezing was higher for larch, as proline is an oxygen free radical scavenger which improves plant resistance to extremely low temperatures (Alia et al. 1995).

\section{Conclusions}

Because of the diverse seasonal needle habits (evergreen, deciduous), there were obvious differences in the allocation of biomass and nitrogen among different organs between pine and larch seedlings at the end of the first growing season. The main nitrogen storage organs of Chinese pine were roots and needles, whereas nitrogen was evenly allocated in roots and stems of Prince Rupprecht's larch. Although the total amino acid contents were not significantly increased by fall fertilization, the higher glutamine levels after fall fertilization may improve the performance of out-planted seedlings of these two species.

Acknowledgements We gratefully acknowledge the reviewers and many other members from the Beijing Forestry University for their insightful comments of the manuscript.

Open Access This article is distributed under the terms of the Creative Commons Attribution 4.0 International License (http://creativeco mmons.org/licenses/by/4.0/), which permits unrestricted use, distribution, and reproduction in any medium, provided you give appropriate credit to the original author(s) and the source, provide a link to the Creative Commons license, and indicate if changes were made.

\section{References}

Alia, Prasad KVSK, Saradhi PP (1995) Effect of zinc on free radicals and proline in Brassica and Cajanus. Phytochemistry 39(1):45-47

Birchler TM, Rose R, Haase DL (2001) Fall fertilization with N and $\mathrm{K}$ : effects on Douglas-fir seedling quality and performance. West J Appl For 16:71-79

Boivin JR, Miller BD, Timmer VR (2002) Late-season fertilization of Picea mariana seedlings under greenhouse culture: biomass and nutrient dynamics. Ann For Sci 59(3):255-264

Boivin JR, Salifu F, Timmer VR (2004) Late-season fertilization of Picea mariana seedlings, intensive loading and outplanting response on greenhouse bioassays. Ann For Sci 61(8):737-745

Grassi G, Millar P, Wendler R, Minotta G, Tagliavini M (2002) Measurement of xylem sap amino acid concentrations in conjunction with whole tree transpiration estimates spring $\mathrm{N}$ remobilization by cherry (Prunus avium L.) trees. Plant Cell Environ 25(12):1689-1699

Grossnickle SC (2005) The importance of root growth in overcoming planting stress. New For 30:273-294

Hu YB, Sun GY (2010) Leaf nitrogen dioxide uptake coupling apoplastic chemistry, carbon/sulfur assimilation, and plant nitrogen status. Plant Cell Rep 29(10):1069-1077

Hu B, Kuster TM, Arend M, Siegwolf R, Rennenberg H (2013) Nitrogen partitioning in oak leaves depends on species, provenance, climate conditions and soil type. Plant Biol 15:198-209

Islam MA, Apostol KG, Jacobs DF (2009) Fall fertilization of Pinus resinosa seedlings, nutrient uptake, cold hardiness, and morphological development. Ann For Sci 66:704-712

Krasensky J, Jonak C (2012) Drought, salt, and temperature stressinduced metabolic rearrangements and regulatory networks. J Exp Bot 63:1593-1608

Lee BR, Lee DG, Avice JC, Kim TH (2014) Characterization of vegetative storage protein (VSP) and low molecular proteins induced by water deficit in stolon of white clover. Biochem Biophys Res Commun 443:229-233

Millard P, Grelet G (2010) Nitrogen storage and remobilization by trees: ecophysiological relevance in a changing world. Tree Physiol 30:1083-1095

Millard P, Proe MF (1991) Leaf demography and the seasonal internal cycling of nitrogen in sycamore (Acer pseudoplatanus L.) seedlings in relation to nitrogen supply. New Phytol 117(4):587-596

Millard P, Proe MF (1992) Storage and internal cycling of nitrogen in relation to seasonal growth of Sitka spruce. Tree Physiol 10(1):33-43

Munoz N, Guerri J, Legaz F, Primo-millo E (1993) Seasonal uptake of ${ }^{15} \mathrm{~N}$-nitrate and distribution of absorbed nitrogen in peach trees. Plant Soil 150(2):263-269 
Nambiar EKS, Fife DN (1991) Nutrient retranslocation in temperate conifers. Tree Physiol 9:185-207

Oliet JA, Salazar JM, Villar R, Robredo E, Valladares F (2011) Fall fertilization of Holm oak affects $\mathrm{N}$ and $\mathrm{P}$ dynamics, root growth potential, and post-planting phenology and growth. Ann For Sci 68:647-656

Oliet JA, Puértolas J, Planelles R, Jacobs DF (2013) Nutrient loading of forest tree seedlings to promote stress resistance and field performance: a Mediterranean perspective. New For 44(5):649-669

Peuke AD (2000) The chemical composition of xylem sap in Vitis vinifera $\mathrm{L}$. cv. Riesling during vegetative growth on three different Franconian vineyard soils and as influenced by nitrogen fertilizer. Am J Enol Vitic 51(4):329-339

Rennenberg H, Dannenmann M, Gessler A, Kreuzwieser J, Simon J, Papen H (2009) Nitrogen balance in forest soils: nutritional limitation of plants under climate change stresses. Plant Biol 11:4-23

Rennenberg H, Wildhagen H, Ehlting B (2010) Nitrogen nutrient of poplar trees. Plant Biol 12(2):275-291

Stepien V, Sauter JJ, Martin F (1994) Vegetative storage proteins in woody plants. Plant Physiol Biochem 32(2):185-192

Van den Driessche R (1985) Late-season fertilization, mineral nutrient reserves, and retranslocation in planted Douglas-fir (Pseudotsuga menziesii (Mirb.) Franco) seedlings. For Sci 31:485-496

Villar-Salvador P, Uscola M, Jacobs DF (2015) The role of stored carbohydrates and nitrogen in the growth and stress tolerance of planted forest trees. New For 46:813-839

Wang J, Li G, Pinto JR (2015) Both nursery and field performance determine suitable nitrogen supply of nursery-grown, exponentially fertilized Chinese pine. Silva Fenn 49(3):1295. https://doi. org/10.14214/sf.1295

Wang J, Yu H, Li G, Zhang F (2016) Growth and nutrient dynamics of transplanted Quercus variabilis seedlings as influenced by prehardening and fall fertilization. Silva Fenn 50(2):1475. https:// doi.org/10.14214/sf.1475
Weber P, Stoermer H, Geßler A, Schneider S, Sengbusch DV, Hanemann U, Rennenberg H (1998) Metabolic responses of Norway spruce (Picea abies) trees to long-term forest management practices and acute $\left(\mathrm{NH}_{4}\right)_{2} \mathrm{SO}_{4}$ fertilization, transport of soluble nonprotein nitrogen compounds in xylem and phloem. New Phytol 140(3):461-475

Wei HX, Xu CY, Ma LY, Duan J, Jiang LN, Ren J (2014) Effect of late-season fertilization on nutrient reserves and carbohydrate accumulation in bareroot Larix olgensis seedlings. J Plant Nutr 37:279-293

Wildhagen H, Dürr J, Ehlting B (2010) Seasonal nitrogen cycling in the bark of field-grown grey poplar is correlated with meteorological factors and gene expression of bark storage proteins. Tree Physiol 30:1096-1110

Wu G, Feng ZW (1994) Study on the social characteristics and biomass of the Pinus tabulaeformis forest systems in China. Acta Ecol Sin $14: 415-422$

Wu B, Nioh I (1997) Growth and water relations of P. tabulaeformis seedlings inoculated with ectomycorrhizal fungi. Microb Environ 12(3):69-74

Zhao Y, Hui W, Li J, Li J, Dong W, Wei H, He CX (2017) Late-season fluxes of ammonium and nitrate in roots of two poplar clones pretreated with nutrient addition. Int J Agric Biol 19:1525-1534

Zhu Y, Dumroese RK, Pinto JR, Li G, Liu Y (2013) Fall fertilization enhanced nitrogen storage and translocation in Larix olgensis, seedlings. New For 44(6):849-861

Publisher's Note Springer Nature remains neutral with regard to jurisdictional claims in published maps and institutional affiliations. 